\title{
SYMBOLIC INTERACTION: MARKETING PUBLIC RELATIONS IN A PRIVATE ISLAMIC UNIVERSITY
}

\author{
Tresna Wiwitan \\ Faculty of Communication Sciences Universitas Islam Bandung \\ Jalan Taman Sari No. 1 Bandung \\ tresna@unisba.ac.id
}

\begin{abstract}
Marketing Public Relations (Marketing PR) activity, including universities Marketing PR is a synergy between marketing and public relation strategies This concept does not only market or sell product/service but also create, nurture and maintain the institution's positive image. Bandung Islamic University (Unisba) is one of the private Islamic universities implementing Marketing PR activity. The objective of this research is to acknowledge and to analyze: 1) the meaning of Marketing PR to Public Relations and Promotional Team, 2) the experience of Public Relations and Promotional Team in conducting the Marketing PR activity. This research uses qualitative research, constructivist paradigm with a phenomenology approach. The theory used is the symbolic interaction and sampling technique is conducted purposively. The result of this research explains that based on the experience, Public Relations and promotional team must have managerial, public speaking and public relations capabilities in educating high school students.
\end{abstract}

Keywords: Promotion; Social Media; Symbolic Interaction

\section{Introduction}

Bandung Islamic University (Unisba) is one of the private Islamic universities with excellent accreditation that always carries out promotion activity in an effort to introduce branding and create good image for the institution. Based on Unisba data almost every year the number of students increases. Based on the data from Unisba's PR (2021): Applicants to Unisba in 2017 were 8,469 , in 2018 were 9,588, in 2019 were 9,968, and in 2020 were 9,407. It showed that the number of applicants to Unisba each year increases despite the insignificant decline by covid-19 outbreak. It affects both economic and educational aspects.

One of the factors of the increasing number of students is the intense Public Relations Marketing activity conducted by Unisba's PR, whether directly or by media. Marketing PR is the synergy between marketing and public relations strategies Marketing PR has a potential to be a leading tool in integrated marketing communication due to the general ability of public relations (PR) to contribute in achieving marketing objectives (Papasolomou \& Melanthiou,

Received: 2021-04-14 | Reviced: 2021-05-17 | Accepted: 2021-06-30

Indexed : Sinta, DOAJ, Garuda, Crossref, Google Scholar | DOI: 10.29313/amwaluna.v5i2.7824 
2012). Marketing PR is the development from the marketing mix; four basic components or elements in the marketing mix, namely product, price, placement and promotion (Athar, 2020). Prita Kemal Gani, the Director of London School of Public Relations (LSPR) when becoming one of the interviewees in the 2016 PR National Convention, states that: "It is no longer denied that nowadays public relations and marketing must be in harmony. The strategy of public relations of an institution must support its marketing activity."

Unisba's PR practitioners routinely conduct roadshows to high schools to perform presentations, participate in education fairs, advertise in various media (newspaper, television and radio), actively interact with students through social media, make publicity in media, cooperate with various schools and give trainings for teachers and high school students. The previous researches prove that "There is a Quietly Meaningful Relation between Marketing PR Activity and Standpoint of High School and Vocational High School Students to Select Unisba" (Wiwitan, Yulianita, \& Fuady, 2016). In order to improve the correlation value between Unisba and the standpoint of High School and Vocational High School students, the program executed by Unisba's PR and promotional team must be planned properly.
When PR makes planning and programs of Marketing PR activity, PR must understand beforehand the meaning based on the institution's mission and vision.

During the covid-19 pandemic, digital Marketing PR activity must be maximized. The use of websites, social media, and Whatsapp is highly preferred to communicate and interact with students. The high number of social media users requires the Public Relations profession to manage social media with integrated strategies to work plan (Arief, Arkan, \& Saputra, 2019). Exhibitions, presentations, and open houses, usually done in person, are now being carried out virtually. That condition produces interactive communication where students can directly ask questions via social media or Whatsapp. Besides, new student registration is also done online. Therefore, all information is submitted online.

Experience is something that has been sustained, gone through, and felt by an individual. Experience becomes the basis of an individual to conduct an action in the future. Weber (Sukidin, 2002) states that in order to understand the motives and meaning of human's action, they must be related with aim. Such rational action is an action aimed on the rational basis of the applicable and affective value, namely action related with intellectual and 
emotional capability, and based on understanding of subjective meaning from the actor itself. It means that an action conducted by an individual shall not be separated from how the individual defines and understands a social reality based on its experience. Contextually in order to compile planning and conduct Marketing PR, PR and promotional team have to understand the meaning and define their experience from the previous years. In order to realize the matters which have been stated before, the focus of this research is to acknowledge and analyze the experience of Unisba's PR and Promotional Team in performing their Marketing PR.

Based on the background of the problem, this article aims to find out; 1) how Unisba's PR and Promotion team experience doing Marketing PR activity and, 2) how to implement symbolic interaction theory in Marketing PR activity.

\section{Research Method}

This research uses qualitative research, in order to study Symbolic Interaction of Marketing $\mathrm{PR}$ to $\mathrm{PR}$ and Unisba's PR Promotion Team, interpreting or defining the experience of Unisba's PR and promotion team in performing Marketing PR. The research shall be conducted through observation, asking questions to interviewees, collecting various specific data, and analyzing data inductively from specific to general. Qualitative research can be used as an alternative to public relations research to produce more indepth information and to naturally describe reality (Kriyantono, 2015). Qualitative method is a research method that produces descriptive analytical data, because it does not use formulas and numbers (Febriadi, 2017).

\section{Research Design}

The method or study used to analyze the matter is phenomenology approach. (Creswell, 2014) Creswell (2014) explains that phenomenology study is to describe general understanding from a number of individuals towards their various life experiences related with concept or phenomenon. Phenomenology is the study of knowledge that comes from consciousness, or how to understand an object or event by experiencing it consciously (Hasbiansyah, 2008). Engkus Kuswarno (2009) states that studies with phenomenology approach try to explain the meaning of life experience of a number of individuals about a concept or symptom (Kuswarno, 2009). In the context of this research, this means that the researcher team tries to explain the meaning of Marketing PR and the experience of Unisba's PR and promotional team on Marketing PR. Phenomenology means letting everything become real as it is, without forcing 
researchers' categories into it. This means that the experience of PR and promotional team in performing some activities becomes the basis of reality.

\section{Discussion}

\section{Experience of Unisba's PR and} Promotional Team in Marketing PR Activity

Experience is something that has been undergone, lived, and felt by someone. Experience becomes the basis for a person to take an action in the future. Based on field findings and interviews with the interviewees concerning their experience in performing Marketing PR activity, an activity that high school students most enthusiastically understood was the presentation at schools because it was conducted directly, face-to-face, and interactively with the students.

One of the most memorable experiences in Unisba activities was conducting presentations in schools. The presentation becomes the most exciting activity due to its direct and interactive information delivered within. High school students were enthusiastic about listening to the presentation material, that is why the PR and promotion team are required to master public speaking skills. One of the abilities, that a Public Relations (PR) practitioner must have, is good communication. PR practitioners are expected to have advanced ability to make good verbal and written communication. Verbal communication includes the ability to speak in public and make a presentation (Hartini, 2019). The presentation also involved selected college students psychologically proven to be closer in terms of ages, experience, and ways of speaking. It aims to produce better interaction among high school students despite a disinclined condition during the presentation. The selected college students have to be eye-catching and good-looking in terms of making high school students enthusiastic. Besides, we also hope that they will not hesitate to ask questions about Unisba.

During the pandemic, Marketing PR activity is carried out online (virtually). The challenges are more severe because presentations, exhibitions, and open houses are conducted online. In virtual presentations, speakers and audiences do not meet face-to-face. Attendance can only be seen from the screenshots while the interaction continues. The concept of a virtual presentation must attract the attention of the audience. In implementing the idea, the presenters have to be well-prepared, ranging from clothes, PowerPoint materials, and material mastery. When delivering material, presenters are expected to be serious, pay attention to nonverbal 
communication, and use communicative, sound, and correct languages.

In managing social media, the Unisba PR and Promotion team have a team that prepares photos, infographics, videos, and captions that will be posted on social media.

Some common themes and schedules have been determined by the team, starting from Monday to Saturday. In addition, the PR and the Promotion team take turns to answer questions on Unisba's social media accounts to measure social media activities using media monitoring practices. Nowadays, a Public Relations practitioner must acquire data analysis skills and carry out analysis using various methods, including analysis techniques, measurement, statistical data, evaluation, and commentary (Arief et al., 2019).

Marketing PR activity is not 'selling' the Unisba. In fact, it provides enlightenment to students about college. By providing information about studying in college, there is no college dichotomy and it is important for high school students to choose college majors earlier in the prospects in spite of direct promotion to high school students. In this context, Marketing PR activity have to prioritize the educational aspect and touch the emotional aspects of high school students. It is in line with the opinion of Thomas L. Harris (2006) (Harris $\&$ Whalen, 2006) regarding Marketing PR, where Marketing PR is informative, persuasive, and educative. A marketing PR practitioner seeks to create a world-ofmouth about a product by generating news from the product, organizing events, and building product educational materials (Santoso \& Toruan, 2018).

PR practitioners must acquire managerial skills to ensure positive relations between organizations and the public (Kriyantono, 2015). As communication managers, PR practitioners act as consultants that identify issues or problems and plan solutions. Besides, they also act as facilitators of two-way communication between the public and the organization. Thus, PR practitioners are responsible for the flow of good communication. They aim to create good coordination and cooperation of various elements in achieving the goals. Human relations capability is related to the personality of PR practitioners in fostering relationships with the public in the context of Marketing PR activity. The nature of PR practitioners is friendly, easy to socialize, and able to produce smooth communication as a determinant of public relations performance (Wardasari, Wisadirana, \& Nasution, 2013). It is in line with the ability to get on with people, fostering networking and relationships with the public involved. Researchers' research in 2015-2016 on "The Relation between Unisba's Marketing PR 
and Students' Standpoint to Select Unisba" indicates that there is relation between presentation and the students' stances to study in Unisba, without setting aside other activity such as participating in educational fairs, advertising in mass media, becoming sponsor for school activities, and giving information through virtual media. One of the advantages of presentation at schools is that PR team and promotional team can directly meet face-to-face with high school students, so that it shall be interactive. The latest research on face-to-face communication states that face-to-face communication is more effective compared to virtual communication (email). The success of face-to-face communication reaches 7 percent while communication by virtual media only reaches success number of 0.21 percent. This research supports the findings of communication experts from France and Finland. Therefore, based on the experience of the interviewees, Marketing PR direct activity shall be based on:

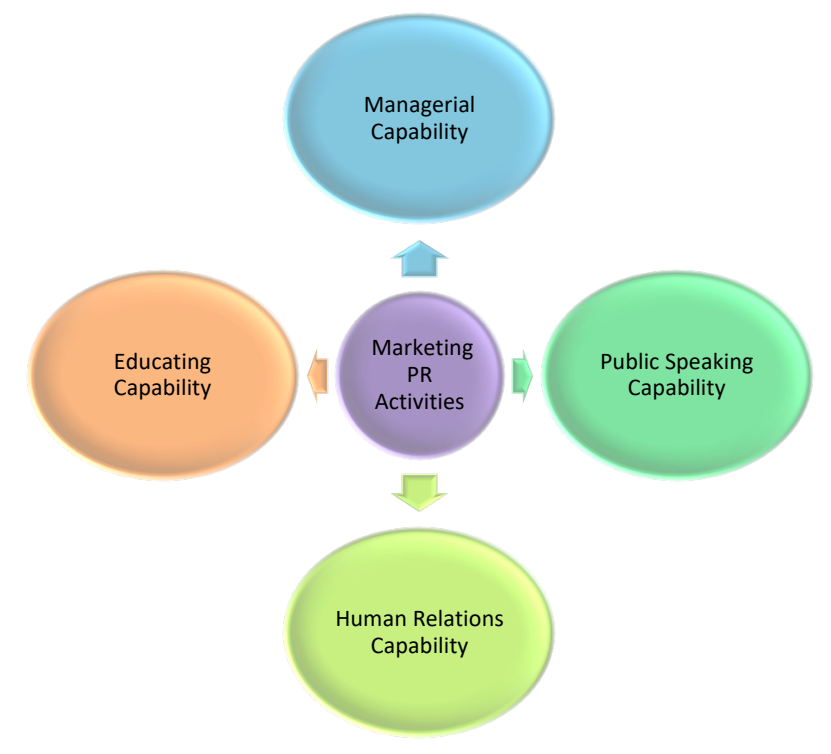

Picture 1

\section{Marketing PR Model based on Experience Aspect}

\section{Source: Researchers' Research}

This research shall be in parallel to the opinion of Thomas L. Harris in his book entitled The Marketer's Guide to Public Relations, which explains that Marketing $\mathrm{PR}$ is not only informative and persuasive but also needs to be educative. Field findings in this research explains that Marketing PR activity in Unisba is not only 'selling' but also needs to educate high school students to face studying activities in the university. Moreover, Unisba's promotional teams must also have managerial capability, public speaking capability and human relations. Rahman (2015) Public Relations as human resources should have the competences that have a sale value in the labor market. Such communication competences include knowledge of communication, 
communication skills, motivation communication, and managing interaction (Rahman, 2015).

Based on researches in the United States, (Putra, 2008) Putra identifies two prominent roles taken by a PR practitioner into a company, namely: managerial role and technician role. Basically, the two roles must complete each other. Therefore, PR program can be properly implemented, directed and right on target. Managerial role conducts planning, leading, regulating schedules, compiling budget, while technician role conducts the entire PR activities. In this Marketing PR activity, promotional team shall be capable to make planning and regulating quite intensive presentation schedules. Moreover, promotional team must be able to manage time provided by schools to do the presentation as clear as possible to the students.

Moreover, Grunig explains the four roles of PR in an organization, namely: 1) event prescriber, meaning that PR helps the management by its experience and skills to find solution for PR problems faced by an organization, 2) communication facilitator, meaning that PR helps the work of the management through cooperation with other divisions in the organization to solve PR problems (in this context, PR is part of the company's management team), 3) problem solving process facilitator, meaning that PR helps the management by creating opportunities to listen to what the public says and to create opportunities that the public shall listen to what the management is expecting, and 4) communication technician, meaning that PR provides communication technical service for the organization (Grunig, 2013).

Based on the four PR roles according to Grunig, Unisba's PR and promotional team shall be capable to conduct the $2^{\text {nd }}, 3^{\text {rd }}$ and $4^{\text {th }} \mathrm{PR}$ roles. It means that to become Unisba's facilitator with schools, they must have the roles to help Unisba's management to solve activity problems and to conduct the various communication activities through media or direct meeting.

\section{Symbolic Interaction in Marketing PR}

Symbolic interaction does not see human acts as stimulus-response, but based on the meaning given to such action. According to Mead (Sukidin, 2002), a human has a number of action possibilities in his/her thought before he/she starts the real action. Before conducting the action, an individual tries beforehand the various alternatives of mental actions through the consideration of his/her reasoning. Thinking is a process where an individual interacts with his/herself using meaningful symbols. Meanwhile according to Blumer (Sukidin, 
2002), symbolic interaction concept refers to unique characteristics of inter-human interaction. Its uniqueness is that humans translate and define not only reaction from an individual's action towards the others, but also each other's actions. Blumer provides three premises of symbolic interaction theory (Kriyantono, 2015); 1) human actions towards other people or something else based on the meanings they give to other people or things, 2) meaning that arises from social interactions conducted by individuals (meaning is negotiated through language), and 3) the individual's thought process that modifies the individual interpretation of symbols. Symbolic interaction describes thinking as an "inner conversation" or dialogue in mind. Contextually, when PR and promotional team do not conduct Marketing PR activity because of the stimulus from high school students, but based on the meaning of the Marketing PR activity. PR and promotional team translate, define and give meaning to Marketing PR, then they conduct Marketing PR activity based on the mission and vision of the institution. When PR and promotional team conduct Marketing PR activity based on the previous experience, the experience is obtained while interacting with students, teachers, parents and other stakeholders, that Marketing PR activity can be perfected. Symbolic interaction assesses that an individual can understand things through learning and experience (Kriyantono, 2015). This experience determines the individual's behavior in the future. Meaning and perception manifest in symbols. Meaning is obtained from the results of interactions with other individuals. Individuals exchange symbols when doing interaction because their perceptions of others are also conveyed by symbols. Ultimately, symbolic interaction can create or change social structures and institutions.

Field findings explain that when PR and promotional team conduct Marketing PR activity, there are several actions need to be considered, namely managerial, public speaking, human relations, and educational capabilities. These four aspects are obtained based on the interpreting, translating and giving meanings from the experience of performing Marketing PR activity of the previous years, not because of stimulus from targets. Therefore, Marketing PR activity can be perfected through evaluation of Marketing PR activity in the previous years. It is in line with Mead's thoughts on the concept of Generalized Other in the theory of symbolic interaction, which explains that each member or employee must work together to achieve the company's targets (Silenzie \& Pribadi, 2020). 
Symbolic interaction theory refers to special interaction characters taking place between humans. Actors are not merely reacting towards the others' actions, but interpreting and defining each action of other individuals (Sukidin, 2002). Actors will choose, examine, think, group and transform meaning in its relation with situation where and to where its action will be directed. Unisba's PR and promotional team as actors in Marketing PR activity may state that 'presentation' is the most effective activity in delivering information on Unisba to high school students, having interpreting and defining their experience of presentation in the previous years.

One of the uniqueness of symbolic interaction theory according to Blumer is that humans translate each other, define their actions, not only reaction and action of an individual towards the others. An individual's response is not made directly from an action, but is based on the 'meaning' given. Therefore, interaction is bridged by the utilization of symbols, interpretation and findings of the meaning of other people's actions. Contextually, PR and promotional team conduct Marketing PR activity as the result of interpreting, defining and giving meaning to their previous experience while performing Marketing PR activity. Therefore, PR and promotional team are actors who realize, reflect, are creative and combine objects they acknowledge through what they call selfidentification. It means that Marketing PR activity is on-going communication process, in which they assess, give meaning and give action in social context.

Referring to Blumer's premise on symbolic interaction theory, 1) PR and promotional team conduct Marketing PR activity based on meanings and interpretation result, 2) meaning is obtained based on social interaction conducted by PR and promotional team with high school students and the schools, and 3) meaning is perfected while the Marketing PR activity takes place.

\section{Conclusion}

Based on the experience of PR and promotional team, Marketing PR activity which has the most interest from high school students is presentation at schools with the 'not selling' technique and 'enlightenment' to students to prepare themselves into universities. When presentation is delivered, PR and promotion team must have managerial, public speaking, human resource and educational capabilities. In addition, PR and promotion team can also manage and monitor social media as the vanguard of Unisba information with the public. Contextually, PR and promotional team conduct Marketing PR activity as the 
result of interpreting, defining and giving meaning to their previous experience while performing Marketing PR activity.

\section{Bibliography}

Arief, N. N., Arkan, M., \& Saputra, A. (2019). Kompetensi Baru Public Relations (Pr) Pada Era Artificial Intelligence Case Study Praktisi Pr D I Indonesia. In Jurnal Sistem Cerdas (Vol. 02).

Athar, H. S. (2020). The Impact Of Marketing Mix On The Purchase Decision When Borrowing Consumer Loans. Amwaluna: Jurnal Ekonomi Dan Keuangan Syariah, 5(1), 40-49. https://doi.org/10.29313/amwaluna.v5i 1.6615

Creswell, J. W. (2014). Penelitian Kualitatif \& Desain Riset: Memilih di Antara Lima Pendekatan. Yogyakarta: Pustaka Pelajar.

Febriadi, S. R. (2017). Aplikasi Maqashid Syariah Dalam Bidang Perbankan Syariah. Amwaluna: Jurnal Ekonomi Dan Keuangan Syariah, 1(2), 231-245. https://doi.org/10.29313/amwaluna.v1i 2.2585

Grunig, L. A. (2013). Toward the Philosophy of Public Relations. Rhetorical and Critical Approaches to Public Relations, II, 65-91.
Harris, T. L., \& Whalen, P. T. (2006). The Marketer's Guide to Public Relations in the 21st Century 1st Edition (1st ed.). California: Belmont.

Hartini, T. (2019). Upaya Perhumas Dalam Meningkatkan Kompetensi Public Relations. Makna: Jurnal Kajian Komunikasi, Bahasa, Dan Budaya, 4(1), 32-57.

Hasbiansyah, O. (2008). Pendekatan fenomenologi: Pengantar praktik penelitian dalam Ilmu Sosial dan Komunikasi. Mediator: Jurnal Komunikasi, 163-180.

Kriyantono, R. (2015). Public Relations, Issue \& Crisis Management: Pendekatan Critical Public Relations, Etnografi Kritis \& Kualitatif. Kencana.

Kuswarno, E. (2009). Fenomenologi: metode penelitian komunikasi: konsepsi, pedoman, dan contoh penelitiannya. Widya Padjadjaran.

Papasolomou, I., \& Melanthiou, Y. (2012). Social Media: Marketing Public Relations' New Best Friend. Journal of Promotion Management, 18(3). https://doi.org/10.1080/10496491.201 2.696458

Putra, I. G. N. (2008). Konteks Historis Praktek Humas Di Indonesia. Jurnal Ilmu Komunikasi , 6(3), 178-190.

Rahman, A. (2015). Kompetensi 
Komunikasi Calon Sdm Public

Relations. Jurnal Visi Komunikasi.

Jurnal Visi Komunikasi, 14, 257-270.

Santoso, P. Y., \& Toruan, R. R. M. L. (2018). Strategi marketing public relations dalam rebranding $\mathrm{HSBC}$ Indonesia untuk membentuk brand awareness. Jurnal Pustaka Komunikasi, 1, 1-14.

Silenzie, R., \& Pribadi, M. A. (2020). Interaksi Simbolik dalam Komunikasi Pemasaran Terpadu di PT. Creative Motion Pctures: Studi Kasus Komunikasi Pemasaran Film Once Upon a Time in Indonesia. Prologia, $4(2)$, 310-315. https://doi.org/10.24912/pr.v4i2.6514

Sukidin, B. (2002). Metode penelitian kualitatif perspektif mikro. Surabaya: Insan Cendekia.

Wardasari, N., Wisadirana, D., \& Nasution, Z. (2013). Kinerja Praktisi Public Relations Dalam Implementasi Kegiatan Human Relations (Studi Kasus Praktisi Public Relations Berdasarkan Latar Belakang Pendidikan non Public Relations pada BUMN Kota Malang). Sosiohumaniora, 15(2), 203-210. https://doi.org/10.24198/sosiohumanio ra.v15i2.5747

Wiwitan, T., Yulianita, N., \& Fuady, M. E. (2016). Hubungan Antara Marketing
Public Relations Dengan Sikap Siswa Sma\&Smk Untuk Memilih Unisba. Prosiding SNaPP: Sosial, Ekonomi Dan Humaniora, 431-444. 